ESJ Humanities

\title{
The Impact of Deductive, Inductive and Mixed Methods of Instruction on EFL Students' Public Speaking Skill (A Case of Georgian Higher Educational Institution)
}

\author{
Ana Gadakhabadze, PhD Candidate \\ Black Sea University, Georgia
}

Doi:10.19044/esj.2021.v17n33p128

Submitted: 09 August 2021

Accepted: 25 August 2021

Published: 30 September 2021
Copyright 2021 Author(s)

Under Creative Commons BY-NC-ND

4.0 OPEN ACCESS

Cite As:

Gadakhabadze A. (2021). The Impact of Deductive, Inductive and Mixed Methods of Instruction on EFL Students' Public Speaking Skill (A Case of Georgian Higher Educational Institution). European Scientific Journal, ESJ, 17 (33), 128.

https://doi.org/10.19044/esj.2021.v17n33p128

\section{Abstract}

The paper aims to assess EFL students' abilities to master public speaking skills at higher educational levels when applying different teaching approaches: inductive, deductive, and mixed (inductive \& deductive) ones. Public speaking samples, namely TED talk videos, were used for observation and inspection during the teaching procedure, accompanied by various public speaking tasks and assessment rubrics that students participated in. The fortyseven video-taped public speaking performances, which were prepared and delivered by the participants, were analyzed and scored with the help of Public Speaking Competence Rubric (PSCR). The speeches were assessed by the researcher and some other expert and non-expert raters, as well as students themselves to maintain objectivity and avoid any kind of bias. Students were all informed about and taught the criteria that the PSCR involves during the studying procedure. The experiment was based on students representing B2 level of English language according to Common European Framework of Reference (CEFR) and it was carried out at one of the private HEIs in Tbilisi, Georgia. Statistical data were collected through pre, while and postexperimental tests in terms of public speaking performance and later analyzed in the SPSS program. According to the research results, TED Talk video samples have a positive impact on EFL students' public speaking skills quality when accompanied by mixed (inductive and deductive) methodological teaching approaches. Particularly they improved their gesturing and posture, 
the majority of them overcame the stage fright (standing and speaking in front of an audience), their speeches became more organized.

Keywords: Public speaking, deductive approach, inductive approach, TED Talks

\section{Introduction}

As society evolves, students require more instruments to learn new information and create discoveries. Teaching or learning a language is a dynamic process in which new approaches and ideas emerge with each new individual coming into contact with it. English instructors have a plethora of materials, ideas, and facilities at their disposal to conduct an effective lesson. Language learning strategies develop in tandem with culture (Harmer, 2007). When communication between nations is at its peak, this is referred to as a communicative technique. These ideas form the foundation of modern language teaching methods (Richards \& Rodgers, 2014). According to Brown (1994), communicative language teaching (CLT) prepares students for reallife situations outside the classroom by providing them with skills and strategies. In short, authenticity in the classroom is critical for improving learners' real-life skills. That is why the ability of public speaking has been stressed at large in the twenty-first century since it integrates all skills crucial for a language student. Teachers must instill in their pupils the importance of thinking creatively, working cooperatively, and speaking boldly. These abilities, which were once considered soft skills, are now more necessary than ever, and teaching public speaking is on the rise at schools and higher educational institutions (HEIs), but not everywhere yet. Georgian HEIs are no exception in this regard; they lack required public speaking courses, particularly those that are linked with L2. So, the author chose to address an existent issue in the country, namely at HEIs, and experimented with one of the private universities to demonstrate the necessity of such courses and the efficacy of the methods used while teaching it.

\section{Literature Review}

According to Shyam and Joy (2016), public speaking is a structured speech pattern given to an audience with three major goals in mind: to inform, persuade and entertain. Public speaking is the way to unlocking empathy, sparking passion, sharing information and ideas, and supporting a common dream (Anderson, 2016). Public speaking is not a new phenomenon and history is replete with instances of great orators and public speakers dating back to ancient Greece and continuing into modern civilization. In the fifth century B.C., the Greeks began to study rhetoric (Kennedy, 2007). According 
to Rapp (2010), rhetoric is the study and practice of persuading audiences via communication.

Current internationalization and globalization tendencies place a great value on strengthening students' communication ability at a higher educational level. (Killick, 2015; Kramsch, 2014; Choudaha \& Wit, 2014). Despite its popularity, CLT is not completely adopted in every country's secondary or higher education system for a variety of reasons like large classrooms, a lack of appropriate teaching materials and textbooks that will primarily focus on improving students' communicative skills, and many more are the primary factors impeding the process's smooth flow (Anderson, 1993; Campbell \& Zhao, 1993; Liao, 2000; Wu, 2011, Savignon, 2002). Another major difficulty is students' L2 level, accompanied by inadequate language skills, which impedes the process of fully implementing CLT and forces teachers to assist them by educating in methods other than CLT. This style of education may result in instructor control, as in traditional classrooms, and therefore the fundamental advantage of CLT, learner-centered instruction, is lost (Yu, 2001; Liao, 2004; Li, 1998; Liao, 2000; Chang, 2011).

Choosing appropriate teaching methods and techniques for a certain EFL community and culture is critical for adopting and integrating public speaking skills (PSS) in the educational environment. Thus, teaching public speaking at higher education institutions is critical because clear teaching standards, appropriate training, and regular practice produce the desired results. For more than a decade, arguments regarding the utility and efficiency of EFL teaching techniques have dominated the educational arena, particularly when comparing deductive versus inductive teaching approaches in teaching English as a Foreign Language. The deductive approach is based on top-down theory, in which language is seen from whole to small pieces, whereas the inductive approach is based on bottom-up theory, in which learning focuses on portions of the language and then generalizes it as the whole (Celce-Murcia \& Olshtain, 2001). Both methods have pros and downsides. Although the deductive approach provides learners with theory, explanation, and problemsolving strategies, it limits students' capacity to think critically and come up with their own answers to issues. In contrast, the inductive approach allows students to draw their own assumptions based on examples and then expand the theory or problem-solving approaches using logical and critical thinking. However, it requires more time and effort to achieve the greatest results (Liu, 2016). According to Swartz (1997), teaching should entail assisting students in discovering methods to improve their language study and make it more concrete and helpful in real-life practices, and this will only happen if learners are actively involved in the construction process and critically examine things. As Dalton (1997) claims "the main point of public speaking is not structure or performance, but rather communicating something meaningful, developing 
ideas, justifying and providing the rationale for arguments, and bringing the community together" (p.7). In today's classroom, there is neither a single obvious and straightforward approach nor style of teaching communication competence nor is it with public speaking skills. Therefore, the experiment will reveal the effectiveness of each approach based on the methodology discussed below and will demonstrate which method works best in applying and implementing public speaking techniques at a higher educational level.

\section{Participants and Sampling}

Totally 47 (20 male and 27 female) students were taking part in the experiment from different faculties: Media which involves students from the faculty of 1) Journalism and Mass communications, 2) Public Relations (PR); department of Governance which involves students from 1) International Relations and Diplomacy, 2) Public Administration; faculty of Economics; and faculty of Humanities and Social Sciences which involves future teachers, psychologists, sociologists. There were three groups: one control group and two experimental groups with varying training methods. For the control group, the researcher used the deductive teaching technique, for experimental group 1 - the inductive teaching strategy, and experimental group 2 - the hybrid teaching approach. Students in the three groups ranged in age from 18 to 21, 35 freshmen, 7 sophomores, and 5 junior ones. All the participants were monolinguals enrolled at the same university learning English as a foreign language. Convenient sampling was used by the researcher as the university administration distributes groups itself. Likewise, the administration tests the students' level based on B2 level (CEFR) tests. For the sake of impartiality and to minimize external variables influencing the outcome, the researcher checked students' learning styles before the experiment began, by using a questionnaire that evaluates students' inductive and deductive learner typology and thinking skills. Based on the six-item questionnaire (see appendix A) it was possible to balance the number of deductive and inductive learners per group so that if the control group had ten deductive learners, the same number of these types of learners should be present in the experimental groups, as well as the number of inductive learners. As a result, any bias resulting from the learners' skills and learner types is eliminated, and the research findings are only the result of teaching techniques, rather than the learners' learning styles or preferences. Here (table 1) is an example of one group (the experimental group 1) and the computation of the proportion of deductive and inductive learners in this group. 
Table 1: The proportion of deductive and inductive learners in experimental group1

\begin{tabular}{|l|l|l|l|l|l|l|}
\hline $\begin{array}{l}\text { B2 level } \\
\text { experimental group 1 }\end{array}$ & \multicolumn{2}{|l|}{ Inductive Questions } & \multicolumn{2}{l|}{ Deductive Questions } \\
\hline Students' codes & Q.1 & Q.3 & Q.6 & Q.2 & Q.4 & Q.5 \\
\hline G008-0001 & 4 & 5 & 4 & 3 & 2 & 1 \\
\hline G008-0002 & 5 & 5 & 4 & 1 & 1 & 1 \\
\hline G008-0003 & 4 & 4 & 4 & 2 & 2 & 1 \\
\hline G008-0004 & 2 & 2 & 1 & 5 & 4 & 4 \\
\hline G008-0005 & 1 & 1 & 2 & 4 & 4 & 4 \\
\hline G008-0006 & 3 & 5 & 4 & 1 & 2 & 3 \\
\hline G008-0007 & 2 & 2 & 1 & 5 & 4 & 3 \\
\hline G008-0008 & 3 & 2 & 3 & 5 & 4 & 4 \\
\hline G008-0009 & 1 & 2 & 1 & 3 & 4 & 5 \\
\hline G008-0010 & 3 & 4 & 4 & 1 & 1 & 1 \\
\hline G008-0011 & 5 & 5 & 5 & 2 & 2 & 1 \\
\hline G008-0012 & 4 & 5 & 4 & 2 & 1 & 3 \\
\hline G008-0013 & 4 & 4 & 5 & 2 & 2 & 1 \\
\hline G008-0014 & 1 & 2 & 2 & 4 & 5 & 5 \\
\hline G008-0015 & 5 & 5 & 5 & 3 & 2 & 3 \\
\hline G008-0016 & 2 & 1 & 1 & 5 & 4 & 3 \\
\hline G008-0017 & 4 & 3 & 4 & 1 & 1 & 2 \\
\hline G008-0018 & 1 & 1 & 1 & 4 & 3 & 3 \\
\hline
\end{tabular}

Deductive learners were labeled in green, whereas inductive learners were coded in yellow. The first three columns show different sorts of inductive questions and students' replies on a 5-point Likert scale ranging from never (1) to always (5). Similarly, the next three columns contain deductive question categories and student replies. We can observe from the data that students marked primarily $3,4,5$ on a Likert scale for inductive question types and mostly 1,2, and sometimes 3 for deductive question types. As a result, these pupils learn inductively. Similarly, pupils who answered 3,4,5 for deductive questions and 1,2,3 for inductive ones are considered to be deductive learners. As a result, we can observe that Experimental group 1 has 10 inductive and 8 deductive learners. The identical process was carried out in experimental group 2 and the control group, with the same proportion of inductive/deductive learners, 10/8 in each group.

The experimental phase was part of a teaching method that lasted one academic semester, particularly 15 weeks. Before the experimental process, the participants were provided with an "informed consent" form (See appendix B) which they were required to sign if they consented to participate in this experiment. All students, both in the experimental and control groups, used the same coursebook, which included authentic listening materials in the form of TED Talks. Pre experimental and Post experimental questionnaires (See appendix $\mathrm{C}$ ) checking students ${ }^{6}$ awareness and progress in public speaking 
were statistically analyzed. The mean, median, mode, standard deviation, skewness, and kurtosis were calculated for each Likert-scale item per group, and based on the findings the answers are claimed to be reliable and trustworthy.

\section{Procedure}

Throughout the semester, it was observed how much working on TED samples improved students' public speaking skills using three different teaching methods: "deductive approach," "inductive approach," and "mixed" to determine which one works best in developing students' public speaking skills in English as a foreign language. PSS improvement was observed almost in every student's case, with slight differences in strong points. The majority of them showed improvements in body language, such as gesture and posture, less movement during speech, and more eye contact with the audience. Some of them represented well-organised structures, giving realia and evidence for their persuasive speeches, etc. To begin, the three groups, taught by the same teacher, used the same coursebook and material and had the same teaching hours. In addition, the time devoted to public speaking discussions and preparations was identical. The semester began and ended at the same time, and the number of public speaking performances was also identical, specifically mini speeches (max 5 mins.)-for preparation and practice 4 times per semester, big speeches (10-12 mins) in terms of pre, while and post-test performances 3 times per semester _ at the beginning of the term to check students' level of public speaking, in the middle of the semester to see how the technique and practice worked in each group's instance, and at the end of the semester after all of the resources for public speaking preparation and practice have been used to see how participants progressed or regressed over the semester. The sole difference between these groups was - teaching methodology: the control group was taught with a deductive approach, experimental group 1- with an inductive approach, and experimental group 2 - with a mixed (inductive + deductive) approach.

In the control group, the instructor began the courses by explaining public speaking skills. Then she distributed ready-made handouts prepared with the assistance of the website www.RateSpeeches.com that contains all the necessary public speaking techniques. Each handout comprised public speaking standards and strategies, as well as terminology and its explanation, so that the students were aware of public speaking guidelines by reading the handout and listening to their instructor's explanation of each word specified in the handout. In certain situations, the instructor was required to interpret some points to make them clearer to the class. After listening to the TED Talk, the students had to check the boxes next to each phrase in the handout that was acted out by the TED speaker and discuss them with their instructor. This sort 
of practice and mastery of public speaking methods occurred 9 times per semester since the teacher had 9 handouts in total, 3 of which focus on PS delivery tactics, 3 on the contents of the speech, and the other 3 handouts typically address time management and slide designs, etc. Furthermore, the teacher gave mini-presentations on public speaking methods once or twice per semester to recap all that had been taught. To summarize, the deductive approach is primarily teacher-centered because the instructor provides all the information and explains the rules and the techniques. Students in this scenario work simply with what their instructor gives them; they do not research PS approaches on their own and do not take an active role in building a critical learning environment.

Students in the inductive and mixed methodological classrooms, on the other hand, actively participated in the creation processes. They created their own handouts and rules and had critical discussions about the topics. Their suggestions were sometimes better and more comprehensive than those in the handouts. The following is the teaching-learning process in experimental group 1, using an inductive classroom setting. First, the instructor collected from students the methods required for public speaking, and after eliciting one or two techniques, the teacher offered students a mini demonstration of how to evaluate each approach. Following that, students viewed the TED talk and wrote notes on some Dos and Don'ts, i.e., likes and dislikes of the speech. The teacher provided pupils with a handout that simply contains the terminology without explanation. Students examined the terminology and attempted to provide their own interpretations for the words defined in the handout. Depending on the number of students in each group, they worked in teams. Each group displayed a self-designed handout with their own explanations and interpretations of the terminology. Students created their own public speaking methods and rules, which they then offered to their peers to compare. If there was a need for clarification of anything, the teacher took open class feedback by asking some questions. To summarize, the teaching/learning approach was entirely student-centered, since each participant was equally involved in the process of developing rules that they would use in the future. The teacher was only a facilitator who was watching to ensure that the process was under control. Every member in each group had their own job: some were writing, others were giving ideas, some were looking for further online materials, and so on.

Similarly, in experimental group 2, with mixed methodological methods, elicitation technique occurred in the same manner as in the inductive group. Here is the procedure for how it was conducted. Firstly, students were given a handout with just terms on it, like in the inductive group, and they worked in the same manner. Collaboration and group work took place while considering some practical explanations and analysis for each provided notion. 
After the completion of the debates in their own groups, they switched places with other students, and two members from each group carried the material to another group to compare and fill up any gaps. Students watched the TED talk to get some ideas from the sample and to check the boxes utilized by the speaker. After summarizing, the teacher distributed a pre-designed handout (the one that was used in the deductive group). Having all the rules and explanations on it, students could compare their thoughts to those provided on the handout with cautious and critical thinking. Each group reflected what they already had and what they added from the handout, resulting in a hybrid form of the rules. Then they watched the Ted talk and marked the items that were performed in the sample, they assessed good and bad points according to the recommendations they had combined.

In short, the students in the control group learn from their instructor, remember the provided information, and try to apply it in their own practice; whereas students in the experimental groups first analyze information based on their own observations, inspect, explore, and create their own versions of handouts, which they then combine with already tried and tested models of the materials and handouts for later application. It is logical to state that when students work on an issue on their own, with or without a team, then listen to others' opinions and suggestions, compare and critically examine the given information, they master any skill much better than the person who is simply a passive listener of the information provided. As a result, it is not surprising that the experimental group students outperformed the control group students over the semester while working on public speaking methods and subsequently delivering their own speeches. It has to be mentioned that a change for the better was observed in the control group as well, albeit not to the same degree as it was in the experimental groups, particularly in the mixed experimental group, where improvement was by far the best and greatest. The result is demonstrated by displaying the findings and statistical calculations below.

\section{Instruments}

The Public Speaking Competence Rubric (PSCR) (See appendix D) by Schreiber (2012) was used to assess each participant's performance using reliable techniques of assessment. PSCR was chosen for a variety of reasons. First and foremost, it is frequently utilized for public speaking evaluation at the higher education level since it is understandable by both students and speech raters. Second, it is an excellent combination of the most necessary PS approaches and includes virtually all key features demonstrated in previous public speaking rubrics such as Thomson and Rucker's (2002), Morreale et al. (2007), Lucas' (2007), AAC\&U's VALUE rubric (Rhodes, 2010), and many more. Some rubrics had too many criteria to look at, while others had too few; 
some provided a comprehensive and exact description of each criterion, while others lacked such accuracy. So, for the experiment, the best option was chosen, which covers nine core competencies and two additional ones to determine a precise level of public speech on a 5-point scale with corresponding scores and descriptors, where band 4 represents an advanced level of PS, 3- proficient, 2- basic, 1- minimal, 0- deficient. Following the selection of the evaluation rubric, the researcher used the tool to test participants' and raters' comprehension of each criterion. The researcher required students' comprehension of the rubric to make them aware of the needs outlined in it for PS development and to test peer evaluation among participants to improve their critical thinking abilities. As a result, it was critical for participants to fully comprehend the rubric. In terms of raters, all three of them had professional experience in assessing speaking, particularly public speaking skills. Two were the researcher and her colleague, both of whom had extensive expertise in the field of EFL teaching and training, as well as extensive experience in public speaking and communicative skill evaluation. The third was a senior student from the faculty of International Relations and Diplomacy at the same university where the experiment was conducted, with extensive experience in public speaking in a variety of fields and venues, such as international conferences, delegating European Parliaments, chairing the IR committee, and so on. Two of the three raters were randomly assigned to alternately attend the participants' public speaking engagements. The third rater afterward watched the recorded films and evaluated the participants. Their assessments of the student's performance were extremely similar as they got full practise and understanding of the rubric that they were going to use for assessment before the experiment, during the so-called "practice session" which lasted for two days. Each day, raters saw three films and evaluated them in separate rooms to retain neutrality and provide unbiased comments. The degree of agreement was calculated through Cronbach Alpha where each set of assessments was higher than 0.8 (between 1 and 0.8 ) and $p=0.000$ which is lower than 0.01 meaning that the results from those raters were trustworthy.

Because the raters' assessments were similar, they attended the students' public speech performances three times per semester at the pre, during, and post-experimental testing procedures and assessed participants' public speaking skills using the rubric mentioned above. Following each stage, the answers were compared and calculated about one another. The results of these assessments, as well as the experiment's outcome, are shown below. 


\section{Results/findings and analysis of the results}

SPSS 16.0 was used to perform statistical analysis on the collected data. The paired-samples t-test was used to determine whether the difference between the control and experimental groups' results was statistically significant.

T-test was calculated using the means of each test:

- for the control group and experimental group 1 (table 2)

- for the control group and experimental group 2 (table 3)

- for experimental groups 1 and 2 (table 4)

Table 2. Summary for T-test (B2 level) Means of Control group and Experimental group 1.

\begin{tabular}{|c|c|c|}
\hline & Control Group & Experimental Group \\
\hline Pre- test & 17.31 & 18.44 \\
\hline While -test & 21.69 & 27.28 \\
\hline Post-test & 25.92 & 35.00 \\
\hline Delayed-test & 19.08 & 29.06 \\
\hline
\end{tabular}

Table 3. Summary for T-test (B2 level) Means of Control group and Experimental group 2.

\begin{tabular}{|c|c|c|}
\hline & Control Group & Experimental Group \\
\hline Pre- test & 17.31 & 18.50 \\
\hline While - test & 21.69 & 28.13 \\
\hline Post-test & 25.92 & 39.56 \\
\hline Delayed-test & 19.08 & 38.38 \\
\hline
\end{tabular}

Table 4. Summary for T-test ( $\underline{\text { B2 level}})$ Means of Experimental group 1 and Experimental group 2.

\begin{tabular}{|c|c|c|}
\hline & $\begin{array}{c}\text { Experimental Group } \\
\text { approach) }\end{array}$ & $\begin{array}{c}\text { Experimental Group }{ }^{2 \text { (mixed }} \\
\text { approach) }\end{array}$ \\
\hline Pre- test & 18.44 & 18.50 \\
\hline While -test & 27.28 & 28.13 \\
\hline Post-test & 35.00 & 39.56 \\
\hline Delayed-test & 29.06 & 38.38 \\
\hline
\end{tabular}

The means at the pre-test level in the control and experimental groups were fairly close to each other in the tables above $(2,3,4)$, indicating that the participants in all groups were more or less at the same level before the experimental treatment. However, as compared to the control group, the mean per group changed substantially in experimental group 1 and dramatically in experimental group 2. The transition from pre-test to while-test and subsequently from while-test to post-test was evident in both experimental groups although it was more pronounced in experimental group 2, where a mixed teaching method was used. 
Table 5. Statistical data of all three groups

\begin{tabular}{|l|l|l|l|l|l|l|}
\hline Groups & $\begin{array}{l}\text { Confidence } \\
\text { interval }\end{array}$ & Mean & Std.Deviation & df & significance & $\mathrm{t}$ \\
\hline Control/Exp.1 & $95 \%$ & 2.28 & 6.35 & 5 & $\mathrm{P}=0.000$ & 8.78 \\
\hline Control/Exp.2 & $95 \%$ & 2.36 & 7.94 & 5 & $\mathrm{P}=0.001$ & 7.31 \\
\hline Exp.1/Exp.2 & $95 \%$ & 2.63 & 8.49 & 5 & $\mathrm{P}=0.001$ & 7.59 \\
\hline
\end{tabular}

To summarize table (5) above, we may state that the difference in the outcomes between the control and experimental groups is statistically significant, because not only did the experimental groups' results grew more than the control group's results, but t-test paired sample statistics revealed the significance (p) which is less than 0.05 in all three situations, demonstrating that there is a statistical difference between the groups and that this difference is statistically important. $T>1$ in all three cases strengthens the fact that significance is important. Furthermore, the statistical Mean of the control and experimental group $2=2.36$ which is greater than the Mean result of control and experimental group $1=2.28$. In other words, $2.36>2.28$, indicating that the difference between the control and experimental groups 2 is greater. Consequently, progress in public speaking abilities was greater among participants in experimental group 2 than in experimental group 1. However, the outcomes were higher in both experimental groups than in the control group. As a result, we may say the experiment was a success.

To strengthen the fact that the experiment was successful, a delayed test was held a month later. The individuals and the surroundings remained the same as they had been during the experiment. As a result, the participants were asked to make one persuasive speech in front of the same audience to demonstrate how their public speaking abilities remained consistent over time. Due to the break between academic semesters, the researcher did not have great hopes of students executing the speeches substantially better than they did the previous time. However, the expectation was that the situation would not be significantly different from the experimental period, and only in that scenario could we have claimed that the experimental treatment had a longterm effect on participants and the experiment was effective. According to tables $(2,3,4)$ above, there was no rise in PSS improvement based on the evaluation they received in the delayed test. However, keeping more or less the same level or very little reduction might also be a sign of a favorable trial outcome. But in the case of the control groups, the decline was fairly obvious, indicating that that sort of approach was inefficient or at least short-termed. As we can see, the control group's mean declined substantially, and from the 
post-test mean result of 25.92 , it plummeted to 19.08 , virtually back to where it was before the experimental period began. In the case of experimental group 1 , it has also reduced, although not as much as in the case of the control group, and from the post-test mean result of 35, it has dropped to 29.06 (delayed test result). In this situation, the mean result remained at the level obtained after the while-test, indicating that the therapy is effective. In the instance of experimental group 2, the change was not as severe as in previous situations, with practically no reduction seen. The mean of the post-test result for experimental group 2 was 39.56, while the mean of the delayed-test result was 38.38. We cannot call it a reduction since, after a while, a shift like this is natural, especially when students were on vacation and, most likely, none of them used public speaking methods during that time. As a result, we can state that the experimental therapy in mixed methodology classrooms was effective and had a long-term influence on the participants.

The same can be asserted using the SPSS tables $(2.1 ; 3.1 ; 4.1$.) below, where we calculated the t-test based on the means, this time incorporating the delayed-test results, and below is the outcome. In table 2.1., where the results of the control group and experimental group 1 are compared, we can see that $\mathrm{t}=10.93$, the confidence interval for the difference is 95 percent, the mean is 2.27, and the standard deviation is 5.88 ; $\mathrm{df}=7, \mathrm{p}=0.000<0.05$; meaning that the difference between the control group and experimental group1 results are statistically important.

Table 2.1: Paired Samples Test for Control and Experimental group 1 (B2 level)

\begin{tabular}{|c|c|c|c|c|c|c|c|c|}
\hline & \multicolumn{5}{|c|}{ Paired Differences } & \multirow[b]{3}{*}{$\mathrm{t}$} & \multirow[b]{3}{*}{$\mathrm{df}$} & \multirow{3}{*}{$\begin{array}{c}\text { Sig. } \\
(2- \\
\text { tailed })\end{array}$} \\
\hline & \multirow[b]{2}{*}{ Mean } & \multirow{2}{*}{$\begin{array}{c}\text { Std. } \\
\text { Deviation }\end{array}$} & \multirow{2}{*}{$\begin{array}{c}\text { Std. Error } \\
\text { Mean }\end{array}$} & \multicolumn{2}{|c|}{$\begin{array}{l}95 \% \text { Confidence } \\
\text { Interval of the } \\
\text { Difference }\end{array}$} & & & \\
\hline & & & & Lower & Upper & & & \\
\hline $\begin{array}{c}\text { Pair 1 VAR00001 - } \\
\text { (scores in } \\
\text { Control } \\
\text { group) } \\
\\
\text { VAR00002 } \\
\text { (scores in } \\
\text { Experimental } \\
\text { group 1) }\end{array}$ & $\begin{array}{r}2.2722 \\
5 \mathrm{E} 1\end{array}$ & 5.88077 & 2.07917 & 17.80605 & 27.63895 & 10.929 & 7 & . 000 \\
\hline
\end{tabular}


Paired Samples Statistics

\begin{tabular}{|r|r|r|r|r|}
\hline Pair 1 & Mean & $\mathrm{N}$ & $\begin{array}{c}\text { Vtd. } \\
\text { Deviation }\end{array}$ & $\begin{array}{c}\text { Std. Error } \\
\text { Mean }\end{array}$ \\
$\begin{array}{c}\text { (scores in } \\
\text { Control } \\
\text { group) }\end{array}$ & 24.2225 & 8 & 6.16284 & 2.17889 \\
$\begin{array}{c}\text { VAR00002 } \\
\text { (scores in } \\
\text { Experimental } \\
\text { group 1) }\end{array}$ & 1.5000 & 8 & .53452 & .18898 \\
\hline
\end{tabular}

Paired Samples Correlations

\begin{tabular}{|c|c|c|c|c|}
\hline & & $\mathrm{N}$ & $\begin{array}{c}\text { Correlatio } \\
\mathrm{n}\end{array}$ & Sig. \\
\hline Pair 1 & $\begin{array}{c}\text { VAR00001 (scores } \\
\text { in Control group) } \\
\& \\
\text { VAR00002 (scores } \\
\text { in Experimental } \\
\text { group 1) }\end{array}$ & 8 & .559 & .150 \\
\hline
\end{tabular}

In table 3.1. where the control group and experimental group 2 results are compared, we can see that $\mathrm{t}=8.21$, confidence interval of the difference is again $95 \%$, mean $=2.46$, Std.Deviation $=8.46, \mathrm{df}=7, \mathrm{p}=0.000<0.05$; meaning that the difference between the control group and experimental group 2 results are statistically important.

Table 3.1. Paired Samples Test for Control and Experimental group 2 (B2 level)

\begin{tabular}{|c|c|c|c|c|c|c|c|c|c|}
\hline & & \multicolumn{5}{|c|}{ Paired Differences } & \multirow[b]{3}{*}{$\mathrm{t}$} & \multirow[b]{3}{*}{$\mathrm{df}$} & \multirow{3}{*}{$\begin{array}{l}\text { Sig. (2- } \\
\text { tailed) }\end{array}$} \\
\hline & & \multirow[b]{2}{*}{ Mean } & \multirow{2}{*}{$\mid \begin{array}{c}\text { Std. } \\
\text { Deviati } \\
\text { on }\end{array}$} & \multirow{2}{*}{$\begin{array}{c}\text { Std. Error } \\
\text { Mean }\end{array}$} & \multicolumn{2}{|c|}{$\begin{array}{l}\text { 95\% Confidence } \\
\text { Interval of the } \\
\text { Difference }\end{array}$} & & & \\
\hline & & & & & Lower & Upper & & & \\
\hline $\begin{array}{c}\text { Pair } \\
1\end{array}$ & $\begin{array}{l}\text { VAR00001 - } \\
\text { (scores in } \\
\text { Control group) } \\
\text { VAR00002 } \\
\text { (scores in } \\
\text { Experimental } \\
\text { group 2) }\end{array}$ & $\begin{array}{r}2.45712 \\
\mathrm{E} 1\end{array}$ & $\begin{array}{r}8.4625 \\
2\end{array}$ & 2.99195 & 17.49641 & 31.64609 & 8.212 & 7 & .000 \\
\hline
\end{tabular}


Paired Samples Statistics

\begin{tabular}{|r|r|r|r|r|}
\hline & Mean & $\mathrm{N}$ & $\begin{array}{c}\text { Std. } \\
\text { Deviation }\end{array}$ & $\begin{array}{c}\text { Std. Error } \\
\text { Mean }\end{array}$ \\
\hline $\begin{array}{r}\text { Pair 1 VAR00001( } \\
\text { scores in } \\
\text { Control } \\
\text { group) }\end{array}$ & 26.0712 & 8 & 8.78204 & 3.10492 \\
$\begin{array}{c}\text { VAR00002 } \\
\text { (scores in } \\
\text { Experimenta } \\
\text { 1 group 2) }\end{array}$ & 1.5000 & 8 & .53452 & .18898 \\
\hline
\end{tabular}

Paired Samples Correlations

\begin{tabular}{|c|c|c|c|c|}
\hline & & $\mathrm{N}$ & $\begin{array}{c}\text { Correlatio } \\
\mathrm{n}\end{array}$ & Sig. \\
\hline Pair 1 & $\begin{array}{c}\text { VAR00001 (scores } \\
\text { in Control group) } \\
\& \\
\text { VAR00002 (scores } \\
\text { in Experimental } \\
\text { group 2) }\end{array}$ & 8 & .617 & .103 \\
\hline
\end{tabular}

In table 4.1, where experimental group 1 and experimental group 2 results are compared, we can see that $\mathrm{t}=9.83$, confidence interval of the difference is again 95\%, mean=2.78, Std.Deviation=8.00, $\mathrm{df}=7$, $\mathrm{p}=0.000<0.05$; meaning that the difference between experimental group1 and experimental group 2 results are statistically important.

Table 4.1. Paired Samples Test for experimental group 1 and experimental group 2 (B2 level)

\begin{tabular}{|c|c|c|c|c|c|c|c|c|c|}
\hline & & \multicolumn{5}{|c|}{ Paired Differences } & \multirow[b]{3}{*}{$\mathrm{t}$} & \multirow[b]{3}{*}{ df } & \multirow{3}{*}{$\begin{array}{l}\text { Sig. (2- } \\
\text { tailed) }\end{array}$} \\
\hline & & \multirow[b]{2}{*}{ Mean } & \multirow{2}{*}{$\begin{array}{l}\text { Std. } \\
\text { Deviati } \\
\text { on }\end{array}$} & \multirow{2}{*}{$\begin{array}{l}\text { Std. } \\
\text { Error } \\
\text { Mean }\end{array}$} & \multicolumn{2}{|c|}{$\begin{array}{l}95 \% \text { Confidence } \\
\text { Interval of the } \\
\text { Difference }\end{array}$} & & & \\
\hline & & & & & Lower & Upper & & & \\
\hline $\begin{array}{c}\text { Pair } \\
1\end{array}$ & $\begin{array}{l}\text { VAR00001 - } \\
\text { (scores in } \\
\text { Experimental } \\
\text { group 1) } \\
\text { VAR00002 } \\
\text { (scores in } \\
\text { Experimental } \\
\text { group 2) }\end{array}$ & $\begin{array}{r}2.77938 \\
\mathrm{E} 1\end{array}$ & 7.99554 & 2.82685 & 21.10931 & 34.47819 & 9.832 & 7 & .000 \\
\hline
\end{tabular}


Paired Samples Statistics

\begin{tabular}{|r|r|r|r|r|}
\hline Pair 1 & Mean & $\mathrm{N}$ & $\begin{array}{c}\text { Vtd. } \\
\text { Veviation }\end{array}$ & $\begin{array}{c}\text { Std. Error } \\
\text { Mean }\end{array}$ \\
\begin{tabular}{|} 
(scores in \\
Experimental \\
group 1) \\
VAR00002 \\
(scores in \\
Experimental \\
group 2)
\end{tabular} & 29.2938 & 8 & 8.10899 & 2.86696 \\
\hline
\end{tabular}

Paired Samples Correlations

\begin{tabular}{|rr|r|r|r|}
\hline & $\mathrm{N}$ & $\begin{array}{r}\text { Correlatio } \\
\mathrm{n}\end{array}$ & Sig. \\
\hline Pair 1 & $\begin{array}{c}\text { VAR00001 (scores in } \\
\text { Experimental group 1) } \\
\&\end{array}$ & & & \\
& 8 & .244 & .561 \\
$\begin{array}{c}\text { VAR00002 (scores in } \\
\text { Experimental group 2) }\end{array}$ & & & \\
\hline
\end{tabular}

\section{Conclusion}

Table 6 below, which summarizes experiment findings for B2 level groups, clearly shows that $\mathrm{T}>1$ in all three situations, indicating that the outcome is already positive. In addition, while determining which experimental group produced a more efficient outcome, we can look at the means, and here we can see that $2.46>2.27$, indicating that experimental group 2 produced a more efficient result based on delayed test results. As a result, we can confidently claim that the combined methodological approach performed far better than the exclusive inductive technique. However, both experimental groups outperformed the control group in terms of efficiency. Particularly in terms of body language, voice control, eye contact, the organizational structure of the speech, even the slide designs, etc. Overall, we can claim that the majority of students' stage fright, which was visible from pre-experimental questionnaire, was overcome during the experiment.

Table 6. Summary of experimental results

\begin{tabular}{|c|c|c|c|}
\hline Groups at B2 level & $\begin{array}{c}\text { Paired sample } \\
\text { T test }\end{array}$ & Mean & $\begin{array}{c}\text { Significance } \\
(\mathbf{p})\end{array}$ \\
\hline Control and Exp.1 & 10.93 & 2.27 & $\mathrm{p}=0.000<0.05 ;$ \\
\hline Control and Exp.2 & 8.21 & 2.46 & $\mathrm{p}=0.000<0.05$ \\
\hline Exp.1 and Exp.2 & 9.83 & 2.78 & $\mathrm{p}=0.000<0.05$ \\
\hline
\end{tabular}




\section{The research limitations and works to be done further}

As for the limitations of the study we can name the number of students per group. We could have more students, but unfortunately, we had to exclude their results from the experiment due to their frequent absence. To generalize the findings in the future, the researcher is planning to conduct a similar experiment at other levels, namely at $\mathrm{C} 1$ (advanced) level, to see whether the procedure and methodology work the same way and gives the same positive result as it happened at B2 level.

\section{References:}

1. Anderson, C (2016). TED Talks: The official TED guide to public speaking. New York, N.Y.: Houghton Mifflin Harcourt

2. Anderson, J. (1993). Is a communicative approach practical for teaching English in China? Pros and cons. System, 21, 471-480.

3. Brown, H. D. (1994). Principles of language teaching, Englewood Cliff. NJ: Prentice-Hall.

4. Campbell, K. \& Zhao, Y. (1993). The dilemma of English language instruction in the people's republic of China. TESOL Journal, 2(4), 46.

5. Celce-Murcia, M., \& Olshtain, E. (2001). Discourse and context in language teaching: A guide for language teachers. Cambridge, England: Cambridge University Press.

6. Dalton, D.G. (1997). Reevaluating the basic public speaking course. Paper presented at the annual meeting of the National Communication Association Convention, Chicago, IL.

7. Harmer, J. (2007). The practice of English language teaching. $4^{\text {th }}$ ed. Harlow: Pearson Longman.

8. Chang, M. (2011). EFL teachers' attitudes toward communicative language teaching in Taiwanese college. Asian EFL Journal Professional Teaching Articles, 53, 17-34.

9. Choudaha, R., \& De Wit, H. (2014). Challenges and opportunities for global student mobility in the future: A comparative and critical analysis. Internationalisation of higher education and global mobility, 23.

10. Kennedy, G.A. (2007). Aristotle on rhetoric. A theory of civic discourse. Oxford: Oxford University Press.

11. Killick, D. (2015). Developing the global student: Higher education in an era of globalization. Internationalization in higher education series. New York: Routledge.

12. Kramsch, C. (2014). Teaching foreign languages in an era of globalization: introduction. The Modern Language Journal, 98, 296311. 
13. Li, D. (1998). It's always more difficult than you plan and imagine: Teachers' perceived difficulties in introducing the communicative approach in South Korea. TESOL Quarterly, 32(4), 677-703.

14. Liao, X. (2004). The need for communicative language teaching in China. ELT Journal,85(3), 270-273.

15. Liao, X. Q. (2000). Communicative language teaching innovation in China: Difficulties and solutions. Educational resources information center. New Zealand. (Eric Document Reproduction Service No. ED 443 294) Retrieved from http://www.eric.ed.gov/PDFS/ED443294.pdf

16. Liu, L. (2016). Using generic inductive approach in qualitative educational research: A case study analysis. Journal of Education and Learning, 5(2), 129-135.

17. Lucas, S. E. (2007). The role of public speaking in China's English language curriculum. In English Public Speaking in Global Context: Challenges and Innovations--The First National Symposium on English Public Speaking.

18. Morreale, S. P. (Ed.). (2007). The competent speaker speech evaluation form. National Communication Association.

19. Rapp, C. (2010). Aristotle's Rhetoric. In E.N. Zalta (Ed.). The Stanford Encyclopedia of Philosophy. Retrieved May 12, 2020, from $<$ https://plato.stanford.edu/archives/spr2010/entries/aristotlerhetoric/>.

20. Rhodes, T. (Ed.). (2010). Assessing outcomes and improving achievement: Tips and tools for using rubrics. Washington, DC: Association of American Colleges and Universities.

21. Richards, J. C., \& Rodgers, T. S. (2014). Approaches and methods in language teaching. Cambridge university press ( $3^{\text {rd }} \mathrm{ed}$.)

22. Savignon, S. J. (2002). Communicative language teaching: Linguistic theory and classroom practice. Mary Jane Peluso. Retrieved from www.yalepress.yale.edu/yupbooks/pdf/0300091567.pdf

23. Shyam, S. S. \& Joy, E.I. (2016). Public speaking skills. In Training Manual on Theeranaipunya - Equipping Fisherwomen Youth for Future, p. 129-132. Kochi: ICAR-Central Marine Fisheries Research Institute.

24. Schreiber, L. M., Paul, G. D., \& Shibley, L. R. (2012). The development and test of the public speaking competence rubric. Communication Education, 61(3), 205-233.

25. Swartz, 0. (1997). Toward a scholarship of social influence: Critical theory, neo-pragmatism, and rhetorical inquiry. Newbury Park, CA: Sage 
26. Thomson, S. \& Rucker, L. M. (2002) The development of a specialized public speaking competency scale: Test of reliability, Communication Research Reports, 19:1, 18-28, DOI: 10.1080/08824090209384828

27. Wu, K. (2011). Teaching and learning English at tertiary level: Revisiting communicative approach; Theory and Practice in Language Studies, 1(11), pp. 1459-1470 Yale University Press.

28. Yu, L. (2001). Communicative language teaching in China: progress and resistance. TESOL Quarterly, 35(1), 179-194.

\section{Appendix A \\ Learner Typology Questionnaire \\ https://forms.gle/UU3mtfJ44nqdZCNf9}

\section{Appendix B}

Informed Consent

https://forms.gle/Nibs9k6pw9vSf8Gn8

\section{Appendix C}

Pre \& Post Experimental Questionnaire

https://forms.gle/5T7TJeYhgZVv46D3A

\section{Appendix D}

PSCR Rubric and Score sheet 


\section{Public Speaking Competence Rubric for Speeches Individual Student Score Sheet}

\section{Name or Participant ID\#-}

\begin{tabular}{|c|c|c|c|c|c|}
\hline \multicolumn{5}{|c|}{ Performance Standards } & \multirow[t]{3}{*}{ Score } \\
\hline $\begin{array}{c}\text { Advanced } \\
4\end{array}$ & $\begin{array}{c}\text { Proficient } \\
3 \\
\end{array}$ & $\begin{array}{c}\text { Basic } \\
2\end{array}$ & $\begin{array}{c}\text { Minimal } \\
1\end{array}$ & $\begin{array}{c}\text { Deficient } \\
0\end{array}$ & \\
\hline \multicolumn{5}{|c|}{ The Student... } & \\
\hline \multicolumn{5}{|c|}{ 1. Selects a topic appropriate to the audience and Occasion } & \\
\hline \multicolumn{5}{|c|}{$\begin{array}{l}\text { 2. Formulates an introduction that Orients audience to topic and } \\
\text { Speaker }\end{array}$} & \\
\hline \multicolumn{5}{|c|}{ 3. Uses an effective Orgenizational pattern } & \\
\hline \multicolumn{5}{|c|}{ 4. Locates, Synthesizes and employs compelling Supporting materials } & \\
\hline \multicolumn{5}{|c|}{$\begin{array}{l}\text { 5. Develops a conclusion that reinforces the thesis and provides } \\
\text { psychological closure }\end{array}$} & \\
\hline \multicolumn{5}{|c|}{ 6. Demonstrates a careful choice of words } & \\
\hline \multicolumn{5}{|c|}{$\begin{array}{l}\text { 7. Effectively uses wocal expression and paralanguage to engege the } \\
\text { audience }\end{array}$} & \\
\hline \multicolumn{5}{|c|}{$\begin{array}{l}\text { 8. Demonstrates nonverbal behavior thet supports the verbal } \\
\text { messoge }\end{array}$} & \\
\hline \multicolumn{5}{|c|}{ 9. Successfully adapts the presentation to the audience } & \\
\hline \multicolumn{5}{|c|}{ 10. Skillfully makes use of visual aids } & \\
\hline \multicolumn{6}{|c|}{$\begin{array}{l}\text { 11. Constructs an effectual persuasive message with credible evidence } \\
\text { and sound reasoning }\end{array}$} \\
\hline \multirow{3}{*}{\multicolumn{5}{|c|}{$\begin{array}{rr}\text { Total Score } \\
\text { Total divided by \# of relevant categories } \\
\text { Public Speaking Proficiency Rating }\end{array}$}} & \\
\hline & & & & & \\
\hline & & & & & \\
\hline
\end{tabular}

\begin{tabular}{|c|c|}
\hline \multicolumn{2}{|c|}{ Proficiency Rating Scale } \\
\hline $4.00-3.50$ & Advanced \\
\hline $3.49-3.00$ & Proficient \\
\hline $2.99-2.50$ & Basic \\
\hline $2.49-1.00$ & Minimal \\
\hline $.99-0$ & Deficient \\
\hline
\end{tabular}

(c) Lisa Schreiber 2010 For use only with author's written permission. 
Public Speaking Competence Rubric for Evaluating Speeches

\begin{tabular}{|c|c|c|c|c|c|}
\hline \multirow{2}{*}{$\begin{array}{l}\begin{array}{c}\text { Performance } \\
\text { Standard }\end{array} \\
\text { The student.... }\end{array}$} & \multicolumn{5}{|c|}{ Assessment Criteria } \\
\hline & $\begin{array}{c}\text { Advanced } \\
4 \\
\end{array}$ & $\begin{array}{c}\text { Proficient } \\
3 \\
\end{array}$ & $\begin{array}{c}\text { Basic } \\
2 \\
\end{array}$ & $\begin{array}{c}\text { Minimal } \\
1 \\
\end{array}$ & $\begin{array}{c}\text { Deficient } \\
0 \\
\end{array}$ \\
\hline $\begin{array}{l}\text { 1. Selects a topic } \\
\text { appropriate to the } \\
\text { audience and } \\
\text { occasion }\end{array}$ & $\begin{array}{l}\text { Topic engages } \\
\text { audience; topic is } \\
\text { worthwhile, timely, } \\
\text { and presents new } \\
\text { information to the } \\
\text { audience }\end{array}$ & $\begin{array}{l}\text { Topic is appropriate } \\
\text { to the audience and } \\
\text { situation and } \\
\text { provides some } \\
\text { useful information } \\
\text { to the audience }\end{array}$ & $\begin{array}{l}\text { Topic is untimely or } \\
\text { lacks originality; } \\
\text { provides scant new } \\
\text { information to } \\
\text { audience }\end{array}$ & $\begin{array}{l}\text { Topic is too trivial, } \\
\text { too complex, or } \\
\text { inappropriate for } \\
\text { audience; topic not } \\
\text { suitable for the } \\
\text { situation }\end{array}$ & $\begin{array}{l}\text { A single topic } \\
\text { cannot be deduced }\end{array}$ \\
\hline $\begin{array}{l}\text { 2. Formulates an } \\
\text { introduction that } \\
\text { orients audience to } \\
\text { topic and speaker }\end{array}$ & $\begin{array}{l}\text { Excellent attention } \\
\text { getter; firmly } \\
\text { establishes } \\
\text { credibility; sound } \\
\text { orientation to topic; } \\
\text { clear thesis; preview } \\
\text { of main points } \\
\text { cogent and } \\
\text { memorable }\end{array}$ & $\begin{array}{l}\text { Good attention } \\
\text { getter; generally } \\
\text { establishes } \\
\text { credibility; provides } \\
\text { some orientation to } \\
\text { topic; discernible } \\
\text { thesis; previews } \\
\text { main points }\end{array}$ & $\begin{array}{l}\text { Attention getter is } \\
\text { mundane; some- } \\
\text { what develops } \\
\text { credibility; } \\
\text { awkwardly } \\
\text { composed thesis; } \\
\text { provides little } \\
\text { direction for } \\
\text { audience }\end{array}$ & $\begin{array}{l}\text { Irrelevant opening: } \\
\text { little attempt to } \\
\text { build credibility; } \\
\text { abrupt jump into } \\
\text { body of speech; } \\
\text { thesis and main } \\
\text { points can be } \\
\text { deduced but are not } \\
\text { explicitly stated }\end{array}$ & $\begin{array}{l}\text { No opening } \\
\text { technique; no } \\
\text { credibility } \\
\text { statement; no } \\
\text { background on } \\
\text { topic; no thesis; no } \\
\text { preview of points }\end{array}$ \\
\hline $\begin{array}{l}\text { 3. Uses an effective } \\
\text { organizational } \\
\text { pattern }\end{array}$ & $\begin{array}{l}\text { Very well } \\
\text { organized; main } \\
\text { points clear, } \\
\text { mutually exclusive } \\
\text { and directly related } \\
\text { to thesis; effective } \\
\text { transitions and } \\
\text { signposts }\end{array}$ & $\begin{array}{l}\text { Organizational } \\
\text { pattern is evident, } \\
\text { main points are } \\
\text { apparent; } \\
\text { transitions present } \\
\text { between main } \\
\text { points; some use of } \\
\text { signposts }\end{array}$ & $\begin{array}{l}\text { Organizational } \\
\text { pattern somewhat } \\
\text { evident; main points } \\
\text { are present but not } \\
\text { mutually exclusive; } \\
\text { transitions are } \\
\text { present but are } \\
\text { minimally effective }\end{array}$ & $\begin{array}{l}\text { Speech did not flow } \\
\text { well; speech was } \\
\text { not logically } \\
\text { organized; } \\
\text { transitions present } \\
\text { but not well formed }\end{array}$ & $\begin{array}{l}\text { No organizational } \\
\text { pattern; no } \\
\text { transitions; sounded } \\
\text { as if information } \\
\text { was randomly } \\
\text { presented }\end{array}$ \\
\hline
\end{tabular}




\begin{tabular}{|c|c|c|c|c|c|}
\hline \begin{tabular}{|l|} 
4. Locates, \\
synthesizes and \\
employs compelling \\
supporting materials
\end{tabular} & $\begin{array}{l}\text { All key points are } \\
\text { well supported with } \\
\text { a variety of credible } \\
\text { materials (e.g. facts, } \\
\text { stats, quotes, etc.); } \\
\text { sources provide } \\
\text { excellent support } \\
\text { for thesis; all sources } \\
\text { clearly cited }\end{array}$ & $\begin{array}{l}\text { Main points were } \\
\text { supported with } \\
\text { appropriate } \\
\text { material; sources } \\
\text { correspond suitably } \\
\text { to thesis; nearly all } \\
\text { sources cited }\end{array}$ & $\begin{array}{l}\text { Points were } \\
\text { generally supported } \\
\text { using an adequate } \\
\text { mix of materials; } \\
\text { some evidence } \\
\text { supports thesis; } \\
\text { source citations } \\
\text { need to be clarified }\end{array}$ & $\begin{array}{l}\text { Some points were } \\
\text { not supported; a } \\
\text { greater quantity/ } \\
\text { quality of material } \\
\text { needed; some } \\
\text { sources of very poor } \\
\text { quality }\end{array}$ & $\begin{array}{l}\text { Supporting materials } \\
\text { are non-existent or } \\
\text { are not cited }\end{array}$ \\
\hline $\begin{array}{l}\text { 5. Develops a } \\
\text { conclusion that } \\
\text { reinforces the thesis } \\
\text { and provides } \\
\text { psychological } \\
\text { closure }\end{array}$ & $\begin{array}{l}\text { Provides a clear and } \\
\text { memorable } \\
\text { summary of points; } \\
\text { refers back to thesis } \\
\text { / big picture; ends } \\
\text { with strong clincher } \\
\text { or call to action }\end{array}$ & $\begin{array}{l}\text { Appropriate } \\
\text { summary of points; } \\
\text { some reference back } \\
\text { to thesis; clear } \\
\text { clincher or call to } \\
\text { action }\end{array}$ & $\begin{array}{l}\text { Provides some } \\
\text { summary of points; } \\
\text { no clear reference } \\
\text { back to thesis; } \\
\text { dosing technique } \\
\text { can be strengthened }\end{array}$ & $\begin{array}{l}\text { Conclusion lacks } \\
\text { clarity; trails off; } \\
\text { ends in a tone at } \\
\text { odds with the rest } \\
\text { of the speech }\end{array}$ & $\begin{array}{l}\text { No conclusion; } \\
\text { speech ends } \\
\text { abruptly and } \\
\text { without closure }\end{array}$ \\
\hline $\begin{array}{l}\text { 6. Demonstrates a } \\
\text { careful choice of } \\
\text { words }\end{array}$ & $\begin{array}{l}\text { Language is } \\
\text { exceptionally clear, } \\
\text { imaginative and } \\
\text { vivid; completely } \\
\text { free from bias, } \\
\text { grammar errors and } \\
\text { inappropriate usage }\end{array}$ & $\begin{array}{l}\text { Language } \\
\text { appropriate to the } \\
\text { goals of the } \\
\text { presentation; no } \\
\text { conspicuous errors } \\
\text { in grammar; no } \\
\text { evidence of bias }\end{array}$ & $\begin{array}{l}\text { Language selection } \\
\text { adequate; some } \\
\text { errors in grammar; } \\
\text { language at times } \\
\text { misused (e.g. jargon, } \\
\text { slang. awkward } \\
\text { structure) }\end{array}$ & $\begin{array}{l}\text { Grammar and } \\
\text { syntax need to be } \\
\text { improved as can } \\
\text { level of language } \\
\text { sophistication; } \\
\text { occasionally biased }\end{array}$ & $\begin{array}{l}\text { Many errors in } \\
\text { grammar and } \\
\text { syntax; extensive } \\
\text { use of jargon, slang. } \\
\text { sexist/racist terms or } \\
\text { mispronunciations }\end{array}$ \\
\hline $\begin{array}{l}\text { 7. Effectively uses } \\
\text { vocal expression } \\
\text { and paralanguage to } \\
\text { engage the audience }\end{array}$ & $\begin{array}{l}\text { Excellent use of } \\
\text { vocal variation, } \\
\text { intensity and pacing: } \\
\text { vocal expression } \\
\text { natural and } \\
\text { enthusiastic; avoids } \\
\text { fillers }\end{array}$ & $\begin{array}{l}\text { Good vocal } \\
\text { variation and pace; } \\
\text { vocal expression } \\
\text { suited to } \\
\text { assignment; few if } \\
\text { any fillers }\end{array}$ & $\begin{array}{l}\text { Demonstrates some } \\
\text { vocal variation; } \\
\text { enunciates clearly } \\
\text { and speaks audibly: } \\
\text { generally avoids } \\
\text { fillers (e.\&. um, uh, } \\
\text { like) }\end{array}$ & $\begin{array}{l}\text { Sometimes uses a } \\
\text { voice too soft or } \\
\text { articulation too } \\
\text { indistinct for } \\
\text { listeners to } \\
\text { comfortably hear; } \\
\text { often uses fillers }\end{array}$ & $\begin{array}{l}\text { Speaks inaudibly; } \\
\text { enunciates poorly; } \\
\text { speaks in } \\
\text { monotone; poor } \\
\text { pacing; distracts } \\
\text { listeners with fillers }\end{array}$ \\
\hline
\end{tabular}




\begin{tabular}{|c|c|c|c|c|c|}
\hline $\begin{array}{l}\text { 8. Demonstrates } \\
\text { nonverbal behavior } \\
\text { that supports the } \\
\text { verbal message }\end{array}$ & $\begin{array}{l}\text { Posture, gestures, } \\
\text { facial expression and } \\
\text { eye contact well } \\
\text { developed, natural, } \\
\text { and display high } \\
\text { levels of poise and } \\
\text { confidence }\end{array}$ & $\begin{array}{l}\text { Postures, gestures } \\
\text { and facial } \\
\text { expressions are } \\
\text { suitable for speech, } \\
\text { speaker appears } \\
\text { confident }\end{array}$ & $\begin{array}{l}\text { Some reliance on } \\
\text { notes, but has } \\
\text { adequate eye } \\
\text { contact, generally } \\
\text { avoids distracting } \\
\text { mannerisms }\end{array}$ & \begin{tabular}{|l|} 
Speaker relies \\
heavily on notes; \\
nonverbal \\
expression stiff and \\
unnatural
\end{tabular} & $\begin{array}{l}\text { Usually looks down } \\
\text { and avoids eye } \\
\text { contact; nervous } \\
\text { gestures and } \\
\text { nonverbal behaviors } \\
\text { distract from or } \\
\text { contradict the } \\
\text { message }\end{array}$ \\
\hline $\begin{array}{l}\text { 9. Successfully } \\
\text { adapts the } \\
\text { presentation to the } \\
\text { audience }\end{array}$ & $\begin{array}{l}\text { Speaker shows how } \\
\text { information is } \\
\text { personally } \\
\text { important to } \\
\text { audience; speech is } \\
\text { skillfully tailored to } \\
\text { audience beliefs, } \\
\text { values, and } \\
\text { attitudes; speaker } \\
\text { makes allusions to } \\
\text { culturally shared } \\
\text { experiences }\end{array}$ & $\begin{array}{l}\text { Speaker implies the } \\
\text { importance of the } \\
\text { topic to the } \\
\text { audience; } \\
\text { presentation is } \\
\text { adapted to audience } \\
\text { beliefs, attitudes and } \\
\text { values; an attempt } \\
\text { is made to establish } \\
\text { common ground }\end{array}$ & $\begin{array}{l}\text { Speaker assumes but } \\
\text { does not articulate } \\
\text { the importance of } \\
\text { topic; presentation } \\
\text { was minimally } \\
\text { adapted to audience } \\
\text { beliefs, attitudes, } \\
\text { and values; some } \\
\text { ideas in speech are } \\
\text { removed from } \\
\text { audience's frame of } \\
\text { reference or } \\
\text { experiences }\end{array}$ & $\begin{array}{l}\text { The importance of } \\
\text { topic is not } \\
\text { established; very } \\
\text { little evidence of } \\
\text { audience } \\
\text { adaptation; speaker } \\
\text { needs to more } \\
\text { clearly establish a } \\
\text { connection with the } \\
\text { audience }\end{array}$ & $\begin{array}{l}\text { Speech is contrary } \\
\text { to audience beliefs, } \\
\text { values, and } \\
\text { attitudes; message is } \\
\text { generic or canned; } \\
\text { no attempt is made } \\
\text { to establish } \\
\text { common ground }\end{array}$ \\
\hline
\end{tabular}

Additional Performance Standards can be found on following page. 


\begin{tabular}{|c|c|c|c|c|c|}
\hline $\begin{array}{l}\text { Additional } \\
\text { Performance } \\
\text { Standards (To be } \\
\text { added to grading } \\
\text { rubric as needed) }\end{array}$ & & & & & \\
\hline $\begin{array}{l}\text { 10. Skillfully makes } \\
\text { use of visual aids }\end{array}$ & $\begin{array}{l}\text { Exceptional } \\
\text { explanation and } \\
\text { presentation of } \\
\text { visual aids; visuals } \\
\text { provide powerful } \\
\text { insight into speech } \\
\text { topic; visual aids of } \\
\text { high professional } \\
\text { quality }\end{array}$ & $\begin{array}{l}\text { Visual aids well } \\
\text { presented; use of } \\
\text { visual aids enhances } \\
\text { understanding: } \\
\text { visual aids good } \\
\text { quality }\end{array}$ & $\begin{array}{l}\text { Visual aids were } \\
\text { generally well } \\
\text { displayed and } \\
\text { explained; minor } \\
\text { errors present in } \\
\text { visuals }\end{array}$ & $\begin{array}{l}\text { Speaker did not } \\
\text { seem well practiced } \\
\text { with visuals; visuals } \\
\text { not fully explained; } \\
\text { quality of visuals } \\
\text { needs improvement }\end{array}$ & $\begin{array}{l}\text { Use of the visual } \\
\text { aids distracted from } \\
\text { the speech; visual } \\
\text { aids not relevant; } \\
\text { visual aids poor } \\
\text { professional quality }\end{array}$ \\
\hline $\begin{array}{l}\text { 11. Constructs an } \\
\text { effectual persuasive } \\
\text { message with } \\
\text { credible evidence } \\
\text { and sound } \\
\text { reasoning }\end{array}$ & $\begin{array}{l}\text { Articulates problem } \\
\text { and solution in a } \\
\text { clear, compelling } \\
\text { manner; supports } \\
\text { claims with } \\
\text { powerful /credible } \\
\text { evidence; } \\
\text { completely avoids } \\
\text { reasoning fallacies: } \\
\text { memorable call to } \\
\text { action }\end{array}$ & $\begin{array}{l}\text { Problem and } \\
\text { solution are clearly } \\
\text { presented; claims } \\
\text { supported with } \\
\text { evidence and } \\
\text { examples; sound } \\
\text { reasoning evident; } \\
\text { clear call to action }\end{array}$ & $\begin{array}{l}\text { Problem and } \\
\text { solution are evident; } \\
\text { most claims are } \\
\text { supported with } \\
\text { evidence; generally } \\
\text { sound reasoning: } \\
\text { recognizable call to } \\
\text { action }\end{array}$ & $\begin{array}{l}\text { Problem and/or } \\
\text { solution are } \\
\text { somewhat unclear; } \\
\text { claims not fully } \\
\text { supported with } \\
\text { evidence; some } \\
\text { reasoning fallacies } \\
\text { present; call to } \\
\text { action vague }\end{array}$ & $\begin{array}{l}\text { Problem and/or } \\
\text { solution are not } \\
\text { defined; claims not } \\
\text { supported with } \\
\text { evidence; poor } \\
\text { reasoning; no call to } \\
\text { action }\end{array}$ \\
\hline
\end{tabular}

